\title{
Iron intakes and dietary sources in two year olds from the Cork BASELINE Birth Cohort Study
}

\author{
E. K. McCarthy ${ }^{1}$, C. Ní Chaoimh ${ }^{1}$, D. M. Murray ${ }^{2,3}$, L. C. Kenny ${ }^{3}$, J. O’B. Hourihane ${ }^{2}$ \\ and M. Kiely ${ }^{1,3}$ \\ ${ }^{1}$ Maternal and Infant Nutrition Research Group, School of Food and Nutritional Sciences, University College Cork, \\ ${ }^{2}$ Department of Paediatrics and Child Health, University College Cork and ${ }^{3}$ The Irish Centre for Fetal and Neonatal \\ Translational Research, Department of Obstetrics and Gynaecology, University College Cork
}

Decreased iron intakes can impact on childhood growth and development and cause iron deficiency anaemia, with the highest prevalence of anaemia among preschool-age children ${ }^{(1)}$. The aim of the current analysis was to quantify iron intakes and dietary sources in the diets of two year olds in Ireland.

Food consumption data was collected in the form of a two day weighed food diary at the 24-month assessment of participants in the Cork BASELINE Birth Cohort Study. Data for 468 participants (median [IQR] age of $2 \cdot 1$ [2·1, 2·2] years) was analysed using the nutritional analysis software WISP ${ }^{\odot}$ (Tinuviel Software), which includes UK and Irish food composition data (EuroFIR) ${ }^{(2)}$.

Of the 468 participants, $51 \%$ were male and the majority of their mothers were Caucasian (99\%) and had a third level education $(89 \%)$. The mean daily intake (MDI) of iron in the total population was $6 \cdot 8 \mathrm{mg}$ and $30 \%$ of children had intakes below the EAR of $5 \cdot 3$ $\mathrm{mg}^{(3)}$. The main sources of iron were breakfast cereals, breads, infant formula/growing-up milks (GUM) and meats, see table. Intakes from the base diet (no fortification) were low as non-consumers of any iron-fortified products, mainly infant formula/GUM and fortified breakfast cereals, had mean iron intakes $\sim 2.0 \mathrm{mg}$ lower than consumers of iron-fortified products $(4.9 \mathrm{vs} .6 .9 \mathrm{mg})$. Consumers of iron-fortified products also had a lower prevalence of inadequate iron intakes (<EAR) compared to non-consumers $(27 \mathrm{vs}$. $65 \%)$. Intakes at the $97 \cdot 5^{\text {th }}$ centile were $12 \cdot 5 \mathrm{mg} /$ day.

From a population perspective, no significant differences in demographic and maternal characteristics were detected between those with adequate iron intakes and those with inadequate intakes. Those with adequate iron intakes had higher energy, protein, carbohydrate and total fat intakes, with increased intakes (g/day) of breads, breakfast cereals, and meats also, compared to those with inadequate iron intakes (all $P<0 \cdot 001$ ). Of those with adequate iron intakes, $95 \%$ were consumers of iron-fortified products compared to $79 \%$ of those with inadequate iron intakes $(P<0 \cdot 001)$.

\begin{tabular}{|c|c|c|c|c|c|c|c|c|c|c|}
\hline & \multicolumn{2}{|c|}{$\begin{array}{l}\text { Total Population } \\
n 468\end{array}$} & \multicolumn{2}{|c|}{$\begin{array}{l}\text { Formula/GUM } \\
\text { Consumers } n 96\end{array}$} & \multicolumn{2}{|c|}{$\begin{array}{l}\text { Formula/GUM } \\
\text { Non Consumers } \\
\text { n } 372\end{array}$} & \multicolumn{2}{|c|}{$\begin{array}{l}\text { Iron-Fortified } \\
\text { Product } \\
\text { Consumers n } 422\end{array}$} & \multicolumn{2}{|c|}{$\begin{array}{l}\text { Iron-Fortified } \\
\text { Product } \\
\text { No-Consumers } \\
n 46\end{array}$} \\
\hline & $\%$ & $\overline{\mathrm{mg} / \mathrm{day}}$ & $\%$ & $\overline{\text { mg/day }}$ & $\%$ & $\overline{\mathrm{mg} / \mathrm{day}}$ & $\%$ & $\overline{\text { mg/day }}$ & $\%$ & $\overline{\mathrm{mg} / \mathrm{day}}$ \\
\hline Break fast Cereals & 31 & $2 \cdot 10$ & 18 & $1 \cdot 61$ & 36 & $2 \cdot 22$ & 32 & $2 \cdot 24$ & 16 & $0 \cdot 81$ \\
\hline Breads and Grains & 14 & 0.92 & 10 & $0 \cdot 96$ & 15 & $0 \cdot 91$ & 13 & 0.93 & 18 & $0 \cdot 88$ \\
\hline Formula/Growing Up Milks & 11 & $0 \cdot 74$ & 40 & $3 \cdot 63$ & 0 & $0 \cdot 00$ & 12 & $0 \cdot 83$ & 0 & $0 \cdot 00$ \\
\hline Meat and Meat Products & 10 & 0.67 & 6 & $0 \cdot 56$ & 11 & $0 \cdot 70$ & 9 & $0 \cdot 66$ & 17 & $0 \cdot 78$ \\
\hline Biscuits and Cakes & 7 & $0 \cdot 46$ & 6 & $0 \cdot 57$ & 7 & $0 \cdot 43$ & 7 & $0 \cdot 48$ & 6 & $0 \cdot 32$ \\
\hline Fruit & 6 & $0 \cdot 40$ & 4 & $0 \cdot 38$ & 7 & $0 \cdot 40$ & 6 & $0 \cdot 40$ & 7 & $0 \cdot 35$ \\
\hline Vegetables & 5 & $0 \cdot 37$ & 4 & $0 \cdot 36$ & 7 & $0 \cdot 38$ & 5 & $0 \cdot 37$ & 9 & $0 \cdot 43$ \\
\hline Milk, Yoghurts, Chesses & 4 & $0 \cdot 25$ & 2 & $0 \cdot 23$ & 4 & $0 \cdot 26$ & 4 & $0 \cdot 25$ & 5 & $0 \cdot 25$ \\
\hline Pulse incl. Baked Beans & 4 & $0 \cdot 30$ & 2 & $0 \cdot 22$ & 5 & $0 \cdot 32$ & 4 & $0 \cdot 29$ & 8 & $0 \cdot 40$ \\
\hline Nutritional Supplements & 1 & $0 \cdot 06$ & 1 & $0 \cdot 05$ & 1 & $0 \cdot 06$ & 1 & $0 \cdot 04$ & 5 & $0 \cdot 26$ \\
\hline Other & 7 & $0 \cdot 48$ & 7 & $0 \cdot 56$ & 7 & $0 \cdot 45$ & 7 & $0 \cdot 47$ & 9 & $0 \cdot 51$ \\
\hline Mean Daily Iron Intake (mg) & \multicolumn{2}{|c|}{$6 \cdot 8$} & \multicolumn{2}{|c|}{$9 \cdot 2$} & \multicolumn{2}{|c|}{$6 \cdot 2$} & \multicolumn{2}{|c|}{$6 \cdot 9$} & \multicolumn{2}{|c|}{4.9} \\
\hline
\end{tabular}

Inadequate intakes of iron were present in nearly a third of two year olds. Iron-fortified products such as breakfast cereals and infant formula/GUM were important sources of iron. As these are predominately non-heme iron sources, the study of the implications of this on iron status are planned in this population group.

Research supported by National Children's Research Centre \& Danone Nutricia Early Life Nutrition.

1. World Health Organisation (2008)

2. www.eurofir.eu

3. Department of Health, UK (1991) 